\title{
POPULATION STRUCTURE OF RHODODENDRON \\ CAMPANULATUM D. DON AND ASSOCIATED TREE SPECIES ALONG THE ELEVATIONAL GRADIENT OF MANASLU CONSERVATION AREA, NEPAL
}

\section{Prabina Rana, Madan Koirala, Dinesh R. Bhuju and Chuenchit Boonchird}

Journal of Institute of Science and Technology

Volume 21, Issue 1, August 2016

ISSN: 2469-9062 (print), 2467-9240(e)

Editors:

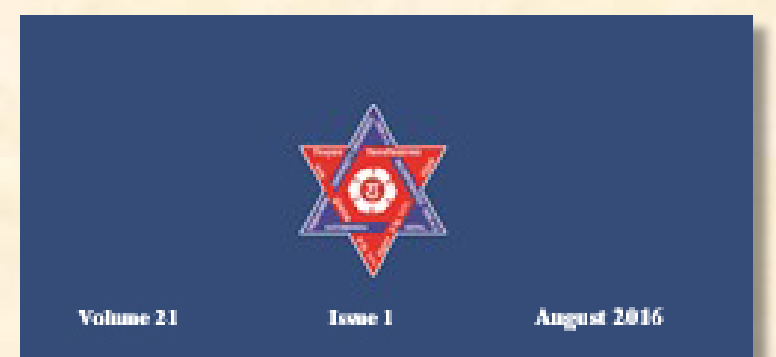

JOURNAL OF INSTITUTE OF

SCIENCE AND TECHNOLOGY

Prof. Dr. Kumar Sapkota

Prof. Dr. Armila Rajbhandari

Assoc. Prof. Dr. Gopi Chandra Kaphle

JIST, 21 (1), 95-102 (2016)

Published by:

Institute of Science and Technology

Tribhuvan University

Kirtipur, Kathmandu, Nepal 


\title{
POPULATION STRUCTURE OF RHODODENDRON CAMPANULATUM D. DON AND ASSOCIATED TREE SPECIES ALONG THE ELEVATIONAL GRADIENT OF MANASLU CONSERVATION AREA, NEPAL
}

\author{
Prabina Rana ${ }^{1,2, *}$, Madan Koirala, ${ }^{1}$ Dinesh R. Bhuju ${ }^{1,2}$ and Chuenchit Boonchird ${ }^{\mathbf{3}}$ \\ ${ }^{1}$ Central Department of Environmental Science, Tribhuvan University, Kirtipur, Nepal \\ ${ }^{2}$ Nepal Academy of Science and Technology (NAST), Nepal \\ ${ }^{3}$ Department of Biotechnology, Mahidol University, Thailand \\ "Corresponding email: prabinar@hotmail.com
}

\begin{abstract}
Climate change is affecting the forest ecosystems worldwide. Impacts of climate change are more perceptible at higher altitudes and can be easily detected along the elevational gradient. The main aim is to study the impact of elevation on the population structure of Rhododendron campanulatum $\mathrm{D}$. Don and associated trees species at Manaslu Conservation Area, central Nepal. A total of 30 quadrats were sampled from 3600-4100 meter above sea level (m asl.) at altitudinal difference of $100 \mathrm{~m}$ with 5 quadrates in each altitude. The present study showed that $R$. campanulatum, Betula utilis, Abies spectabilis and Sorbus microphylla are the treeline species. $R$. campanulatum was the most dominant species with highest importance value index (IVI) along the altitudinal gradient. At $4000 \mathrm{~m}$ asl. $S$. microphylla was the codominant species. B. utilis was the codominant species at $3600-3900 \mathrm{~m}$ asl followed by $S$. microphylla and A. spectabilis. $R$. campanulatum and A. spectabilis showed a sustainable regeneration. No seedling of $B$. utilis was found along the altitudinal gradient indicating that the regeneration of this species might be affected by unfavourable micohabitat (eg. deep shade). $R$. campanulatum and $S$. microphylla were found above the treeline indicating that the climatic conditions were favourable for their growth. The height, diameter and density of the species differed along the elevational gradient and showed a species specific trend.
\end{abstract}

Key words: Treeline ecotone, Regeneration, Climate change, Elevation gradient, Density

\section{INTRODUCTION}

The average temperature of the Earth's surface has increased by approximately $0.8^{\circ} \mathrm{C}$ in the past 100 years (IPCC 2014). Temperature rise is much higher at higher altitudes than at lower (IPCC 2014, Shrestha 1999). High mountain areas where low temperatures limit plant life are highly vulnerable to the impacts of climate change (Grabher et al. 1994). Climate change affects the distribution, population structure and regeneration of tree species at high altitudes (Payette et al. 1985, Kullman 2002, Camarero \& Gutierrez 2004). Different environment gradients are formed on mountain slopes as the air temperature decreases on an average by $0.6^{\circ} \mathrm{C}$ per $100 \mathrm{~m}$ on the altitudinal gradient (Shrestha 1999). Environmental conditions differ greatly with altitude thus the limiting factors related to seedling establishment and tree recruitment might vary with changes in altitude (Block \& Tretor 2001, Wangda \& Ohsawa 2006, Penuelas et al. 2007). The understanding of environmental influences on population structure and regeneration dynamics of the natural forests could be improved by studies that sample across the distributional range (Veblen 1989, Wang et al. 2004, Wangda \& Ohsawa 2006, Penuelas et al. 2007, Lingua et al. 2008). Population structure studies along the altitudinal gradient could be instrumental in giving us insight about the influence of environment factors on the regeneration of natural forests (Wang et al. 2004). Rhododendron campanulatum D. Don a member of Ericaceae family is found at the treeline ecotone, timberline and subalpine forest in Nepal. However, limited studies have been carried and there is lack of baseline data regarding the regeneration potential and population structure of tree species along the altitudinal gradient of High Himalaya, Nepal. Bearing this in mind an attempt was made to assess the impacts altitude and climate on the population structure of $R$. campanulatum and associated tree species at Manaslu Conservation Area. 


\section{MATERIALS AND METHODS}

\section{Study area}

The study site lies in Manaslu Conservation Area (MCA) a protected site established in 1998 and situated in central Nepal covering an area of 1663 square kilometers. MCA protects 2,000 species of flowering plants and 11 types of forest have been reported in this area (NTNC 2010). It has a diverse natural resource base with sparse human population and is relatively inaccessible. The area includes nine bioclimatic zones ranging from the lower subtropics to the nival zone minimal infrastructures such as walking trails. Sparsely distributed local people rely on agriculture, animal husbandry and utilization of natural resources for their existence. The sampling site in the sub alpine forests are primarily composed of Betula utilis and Abies spectabilis with Rhododendron campanulatum and Sorbus microphylla forming the second tree layer. The species limit of A. spectabilis was recorded at $3984 \mathrm{~m}$ asl. and its treeline at $3907 \mathrm{~m}$ asl. whereas for $B$. utilis the treelimit and treeline was recorded at $3990 \mathrm{~m}$ asl. (Gaire et al. 2014). The tree canopy of treeline ecotone is formed by $B$. utilis and A. spectabilis, $R$. campanulatum and $S$. microphylla. Above the treeline scrubs of Rhododendron anthopogen and herbaceous species occur. Records from nearby meteorological stations in Chame reveal that over the past 30 years, the area experienced a decreasing trend in rainfall by $3.9 \mathrm{~mm} /$ year and an increasing trend in mean annual temperature by 0.017 ${ }^{\circ} \mathrm{C} /$ year (Gaire et al. 2014). Further the monthly mean minimum temperature has been decreasing

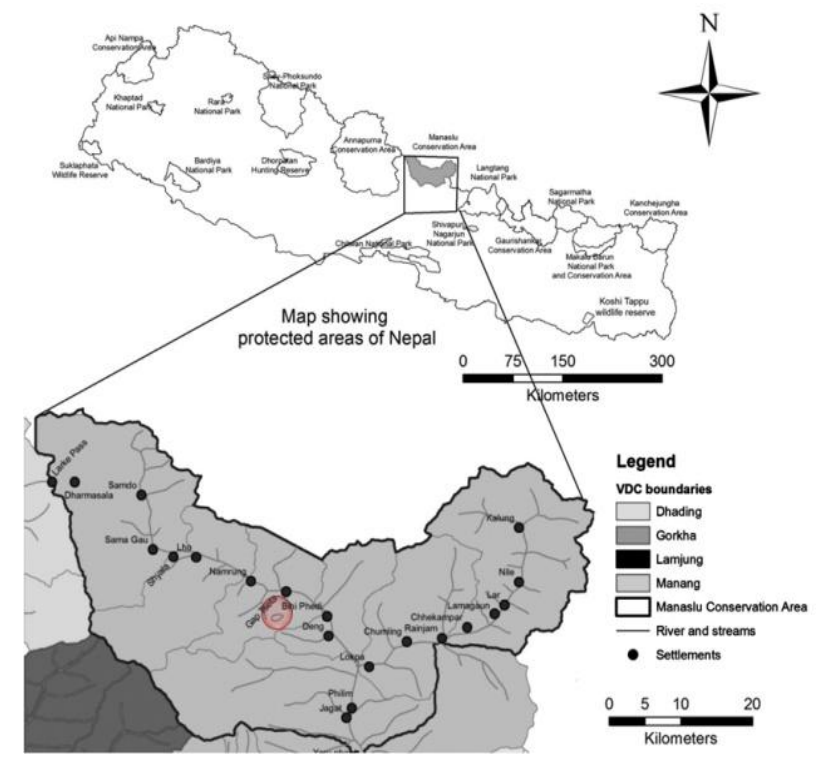

Fig. 1. Map of the study site, Manaslu Conservation Area, central Nepal. while monthly mean maximum temperature has been significantly increasing (Gaire et al. 2014).

\section{Methodology}

Field study was carried in March-April 2012 and 2013 in the north facing mountain slope above and adjacent to the Kalchuman Lake in central Nepal (Fig 1). The population structure of $R$. campanulatuam and tree species were studied using quadrat method. A total of 30 quadrats $(10 \mathrm{~m} \times 10 \mathrm{~m})$ were sampled from 3600 meter above sea level ( $\mathrm{m}$ asl.) to $4100 \mathrm{~m}$ asl. at an altitudinal difference of $100 \mathrm{~m}$ starting from the species limit of $R$. campanulatum. The study area was divided into five vertical transects and in each transect five quadrats were horizontally spaced $50 \mathrm{~m}$ apart. In each quadrat $R$. campanulatum and associated tree species were enumerated into three height classes: tree $(>2 \mathrm{~m})$, saplings $(0.5-2 \mathrm{~m})$ and seedling $(0.5 \mathrm{~m})$ according to Wang et al., (2006) and Kullman (2007). Seedling and saplings were also enumerated within the same $10 \times 10 \mathrm{~m}$ quadrats. In each quadrat all individuals of $R$. campanulatum and associated species were recorded and their height and diameter at breast height (DBH measured at $137 \mathrm{~cm}$ above the ground) were measured. The geographical location of each quadrat (longitude, latitude and altitude) was recorded using Garmin e-trex Global Positioning System (GPS). The vegetation data were quantitatively analyzed for basal area, density, frequency according to Kershaw (1973). The IVI of tree species were calculated by summing up the relative values of frequency, density and basal area where the relative value of frequency, density and basal area were derived as the value for a species expressed as percentage of the sum of those values for all the species of the community (Kershaw 1973). Those species having maximum IVI were considered as dominant species. For some of the pair of variables scatter diagram were plotted.

\section{RESULTS AND DISCUSSION}

At $4100 \mathrm{~m}$ asl., only seedlings and saplings of Rhododendron campanulatum were present. At $4000 \mathrm{~m}$ asl., which lies above the treeline $R$. campanulatum was the dominant species with the highest value of IVI180 species and density of 140 trees per hectare and Sorbus microphllya was the co-dominant tree species with the IVI value of 120 and density of 80 trees per hectare. 
Table 1. Frequency, density, total basal area (TBA) and important value index (IVI) of Rhododendron campanulatum and associated tree species along the elevational gradient.

\begin{tabular}{|c|c|c|c|c|c|}
\hline Altitude & Species & $\begin{array}{c}\text { Frequency } \\
(\%)\end{array}$ & $\begin{array}{c}\text { Density of } \\
\text { trees /ha }\end{array}$ & TBA $\mathrm{m}^{2} / \mathrm{ha}$ & IVI \\
\hline \multirow[t]{4}{*}{$3600 \mathrm{~m}$ asl } & Rhododendron campanulatum & 100 & 940 & 10.81 & 144 \\
\hline & Betula utilis & 100 & 200 & 11.23 & 91 \\
\hline & Abies spectabilis & 40 & 40 & 2.30 & 25 \\
\hline & Sorbus microphylla & 80 & 160 & 0.76 & 25 \\
\hline \multirow[t]{4}{*}{$3700 \mathrm{~m}$ asl } & Rhododendron campanulatum & 100 & 400 & 6.06 & 140 \\
\hline & Betula utilis & 80 & 180 & 4.34 & 89 \\
\hline & Abies spectabilis & 40 & 40 & 0.38 & 23 \\
\hline & Sorbus microphylla & 60 & 120 & 1.34 & 49 \\
\hline \multirow[t]{4}{*}{$3800 \mathrm{~m}$ asl } & Rhododendron campanulatum & 100 & 580 & 8.13 & 138 \\
\hline & Betula utilis & 80 & 180 & 7.67 & 87 \\
\hline & Abies spectabilis & 60 & 60 & 0.9 & 31 \\
\hline & Sorbus microphylla & 60 & 60 & 1.71 & 44 \\
\hline \multirow[t]{4}{*}{$3900 \mathrm{~m}$ asl } & Rhododendron campanulatum & 100 & 820 & 10.69 & 168 \\
\hline & Betula utilis & 100 & 220 & 4.95 & 82 \\
\hline & Abies spectabilis & 0 & 0 & 0 & 0.0 \\
\hline & Sorbus microphylla & 100 & 140 & 0.89 & 51 \\
\hline \multirow[t]{4}{*}{$4000 \mathrm{~m}$ asl } & Rhododendron campanulatum & 40 & 140 & 1.00 & 180 \\
\hline & Betula utilis & 0 & 0 & 0 & 0 \\
\hline & Abies spectabilis & 0 & 0 & 0 & 0 \\
\hline & Sorbus microphylla & 20 & 80 & 0.83 & 121 \\
\hline
\end{tabular}

At $3900 \mathrm{~m}$ asl which is below the treeline $R$. campanulatum was the dominant species with an IVI of 168 and density of 820 trees per hectare other associated tree species were Betula utilis and $S$. microphylla. The high density of $R$. campanulatum trees at this altitude with high basal area $\left(10.69 \mathrm{~m}^{2} / \mathrm{ha}\right)$ might have created an unfavorable niche for seedling and sapling establishment of $R$. campanulatum and associated tree species as seen in Table 1 (Fig. 2 \& 3). Rhododendrons are also reported to have alleopathic effect which affects seedling establishment (Schickhoff et al. 2015). At $3800 \mathrm{~m}$ asl. $R$. campanulatum was the dominant species with IVI of 138 and density of 580 trees per hectare. Other associated tree species recorded were B. utilis, A. spectabilis and S. microphylla. The density and IVI for of A. spectabilis peaked at this altitude indicating that this altitude is favourable for its growth. At $3700 \mathrm{~m}$ asl. $R$. campanulatum was still the dominant species. B. utilis showed a similar trend of IVI and density at $3800 \mathrm{~m}$ asl., $3700 \mathrm{~m}$ asl. and $3600 \mathrm{~m}$ asl. The density of $R$. campanulatum decreased from $3900 \mathrm{~m}$ asl to $3700 \mathrm{~m}$ asl and slightly increased at $3600 \mathrm{~m}$ asl. The decrease in density may be due to low precipitation and low moisture at lower elevation and competition between species. According to Whittaker (1956), Block and Tretor (2001) low precipitation and low soil moisture at the low elevations could restrict growth and development of plants in the soil. The change in overall density of woody species due to change in elevation is closely related to both temperature and precipitation along steep elevational gradients along with other factors (Bai et al. 2011). 


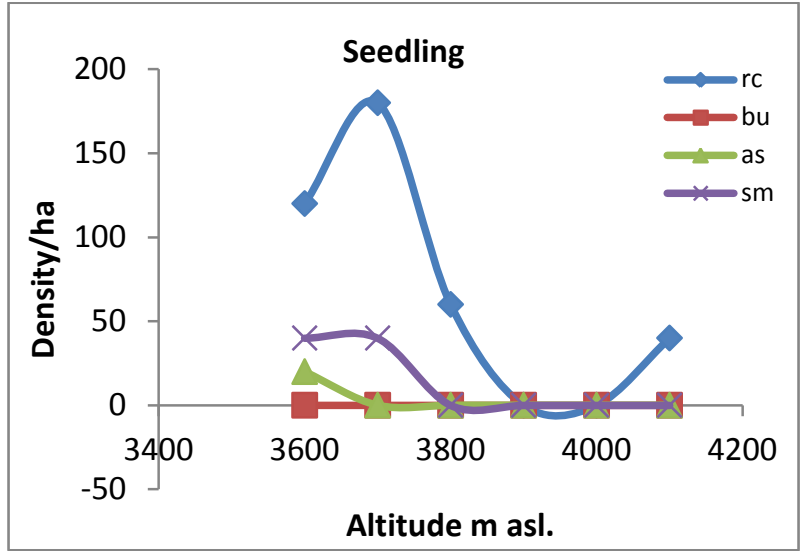

Fig. 2. Seedling density of Rhododendron campanulatum (rc), Betula utilis (bu), Abies spectabilis (as) and Sorbus microphylla (sm) along the elevation gradient in Manaslu Conservation Area, central Nepal.

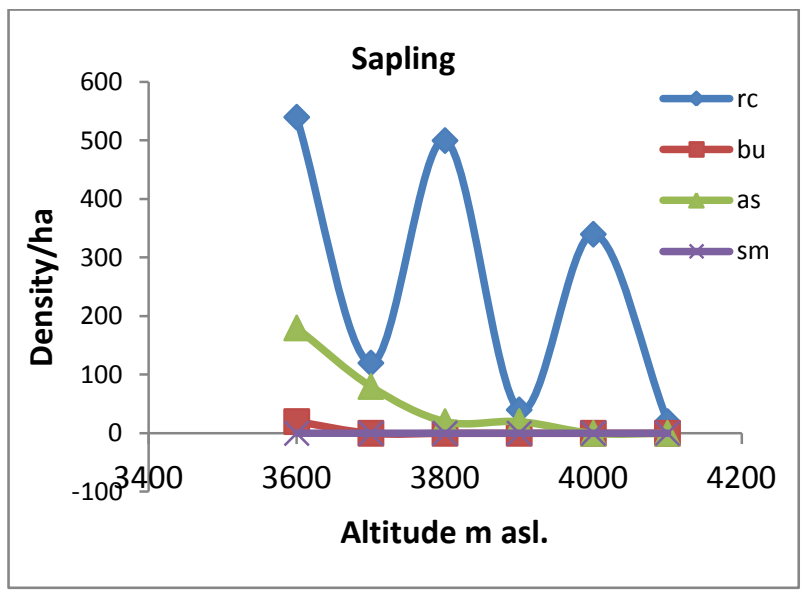

Fig. 3. Sapling density of Rhododendron campanulatum (rc) and Betula utilis (bu), Abies spectabilis (as) and Sorbus microphylla (sm) along the elevation gradient in Manaslu Conservation Area, central Nepal.

Altogether three tree species viz. A. spectabilis, $S$. micropylla and B. utilis were found to be associated with $R$. campanulatum (Table 1). Gaire et al. (2014) also reported these species as treeline species in Manaslu Conservation Area. The density of $R$. campanulatum and associated species showed a fluctuating trend along the altitudinal gradient. The variation among the density of seedling, saplings and trees may be due to climatic (temperature and moisture) as well as edaphic factors. Tasfeye et al. (2010) reported similar variation in seedling density along the altitudinal gradient in Southern Ethopia.

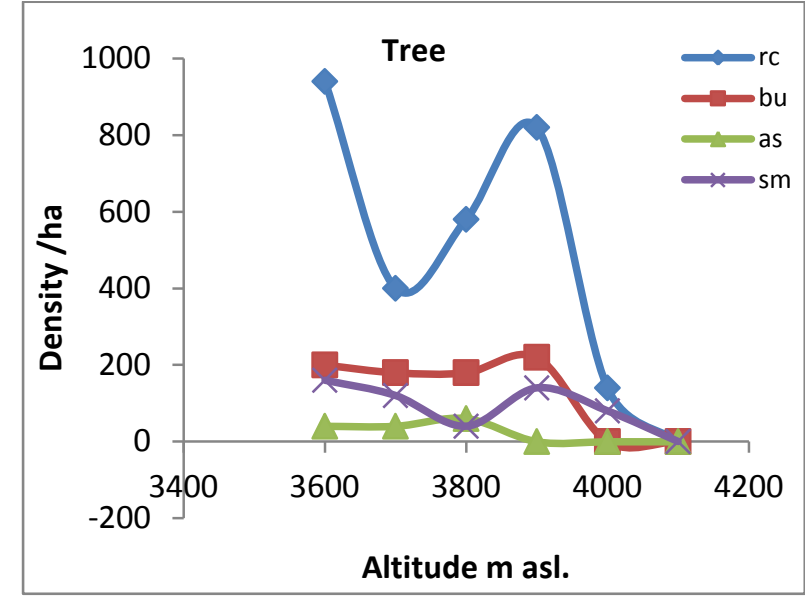

Fig. 4. Tree density of Rhododendron campanulatum (rc) and Betula utilis (bu), Abies spectabilis (as) and Sorbus microphylla (sm) along the elevation gradient in Manaslu Conservation Area, central Nepal.

The density of tree, sapling and seedling of $R$. campanulatum peaked at $3600 \mathrm{~m}$ asl, $3800 \mathrm{~m}$ asl and $3700 \mathrm{~m}$ asl respectively (Fig., 2, 3 \& 4). At $3900 \mathrm{~m}$ asl, high basal area, density and allelopathic effect of Rhododendron may have been detrimental for the survival of seedlings and saplings of $R$. campanulautum and associated species at this altitude (Fig. 4). The density of seedling of $R$. campanulatum and $S$. microphylla were higher at $3600 \mathrm{~m}$ asl and $3700 \mathrm{~m}$ asl. a mixed forest of $R$. campanulatum, $B$. utliis, A. spectabilis and S. microphylla (Fig. 2). Wardle (1971) reported that seedling density often increases with decreasing altitude. $R$. campanulatum saplings fluctuated along the altitudinal gradient while A. spectabilis saplings increased at $3600 \mathrm{~m}$ asl. and $3700 \mathrm{~m}$ asl. Higher presence of seedlings in gaps could be attributed to many factors such as better germination capacity, higher percentage survival in gap areas etc. (Arista 1995, Liu 2004). Hardly any seedling and saplings of $B$. utilis was recorded. Since this is an early successional species, it requires direct sunlight (e.g. in gaps) for seedling establishment. $R$. campanulatum often forms dense stand with deep shade where seedling establishment of Betula is almost impossible. Lack of seedling of Betula might be due to unfavorable microhabitat (e.g. deep shade) (Shrestha et al. 2010). Gaire et al. (2014) also reported a similar finding in his study at Manaslu Conservation Area. The deep shade made by shade tolerant species will replace shade intolerant species (Grime 2001). Therefore, B. utilis could be replaced by a shade tolerent $A$. spectabilis at lower elevations. Liang et al. (2014) reported that the growth of Betula 
at the upper timberlines is limited by moisture. Sujakhu (2013) also emphasized that the current environment conditions were not favourable for the establishment of $B$. utilis seedlings. Moisture and deep shade might be detrimental for seedling establishment. The total sapling density of all tree species was higher than seedling density which is not a normal demographic development. Similar trend was also observed by Gaire et al. 2010 at Langtang and Sujakhu (2013) at Samagoan. There is a positive relationship between total basal area and seedling and sapling (Fig. $5 \& 6$ ). However, the relation between seedling and stand is weak.

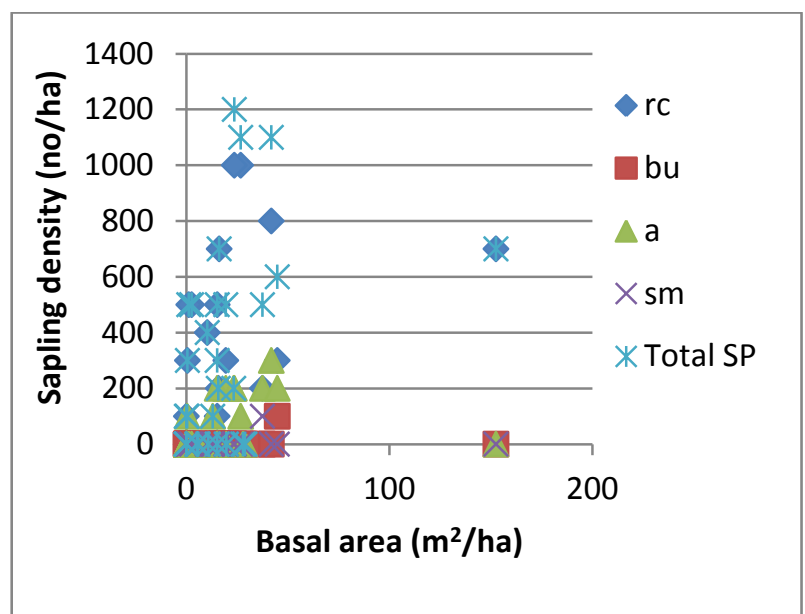

Fig. 5. Scatter diagram showing variation of sapling density with basal area of Rhododendron campanulatum and associated tree species in Manaslu Conservation Area, central Nepal.

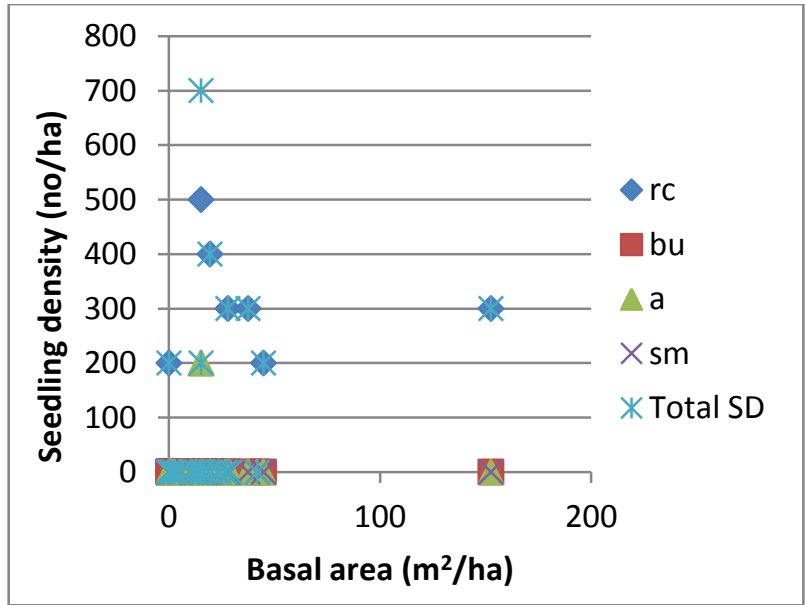

Fig. 6. Scatter diagram showing variation of sapling density with basal area of Rhododendron campanulatum and associated tree species in Manaslu Conservation Area, central Nepal.

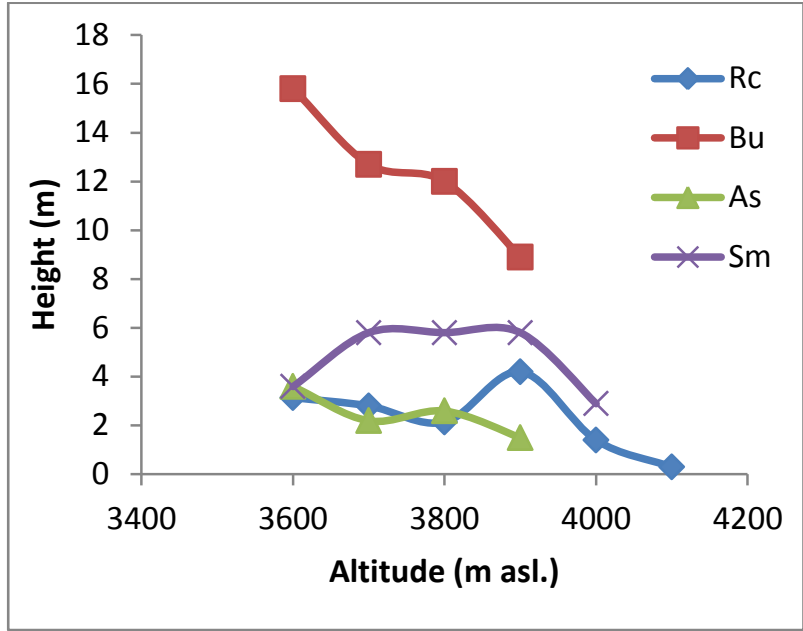

Fig. 7. Average height of Rhododendron campanulatum and associated tree species along the elevational gradient in Manaslu Conservation Area, central Nepal.

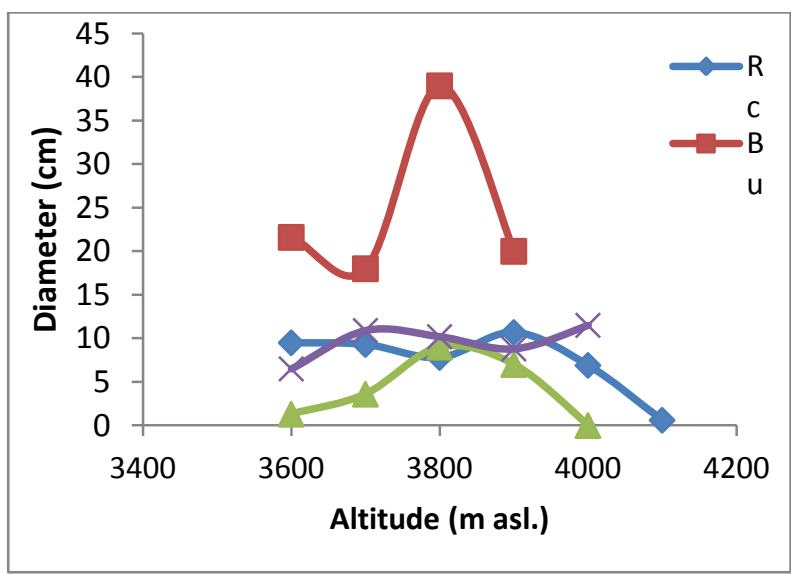

Fig. 8. Average diameter of Rhododendron campanulatum and associated tree species along the elevational gradient in Manaslu Conservation Area, central Nepal.

The average height of $R$. campanulatum and associated tree species showed a different trend along the altitudinal which was species specific (Fig. 7). The height of B. utilis decreased with elevation. The average height $(\mathrm{m})$ of $R$. campanulatum peaked at $3900 \mathrm{~m}$ asl. tapering towards higher and lower altitude. The average height $(\mathrm{m})$ of $S$. microphylla peaked at $3700 \mathrm{~m}$ asl., $3800 \mathrm{~m}$ asl. and $3900 \mathrm{~m}$ asl. The height $(\mathrm{m})$ of $A$. spectabilis also decreased with increasing altitude. The average diameter $(\mathrm{cm})$ of $R$. campanulatum, $B$ utilis, $A$. spectabiis and $S$. microphylla peaked at $3900 \mathrm{~m}$ asl., $3800 \mathrm{~m}$ asl. and $4000 \mathrm{~m}$ asl. respectively (Fig. 8). 


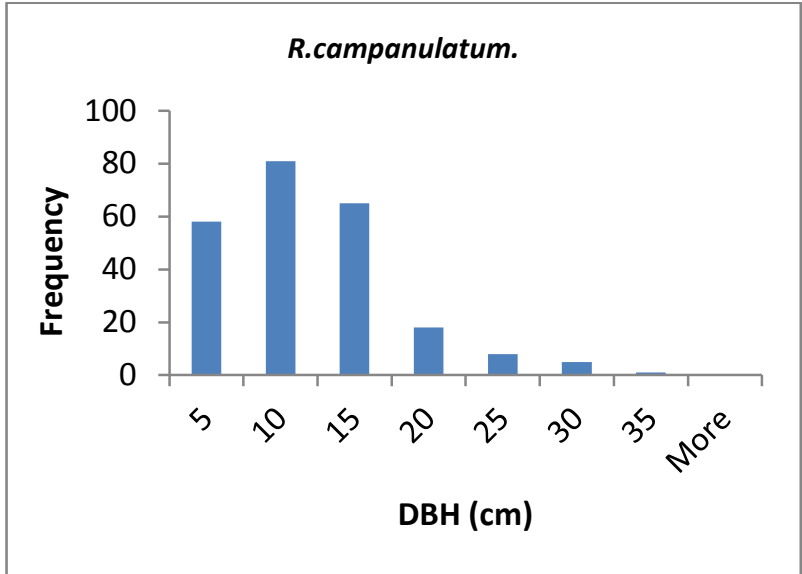

Fig. 9. DBH class distribution of Rhododendron campanulatum, Kalchuman Tal area of Manaslu Conservation area, central, Nepal.

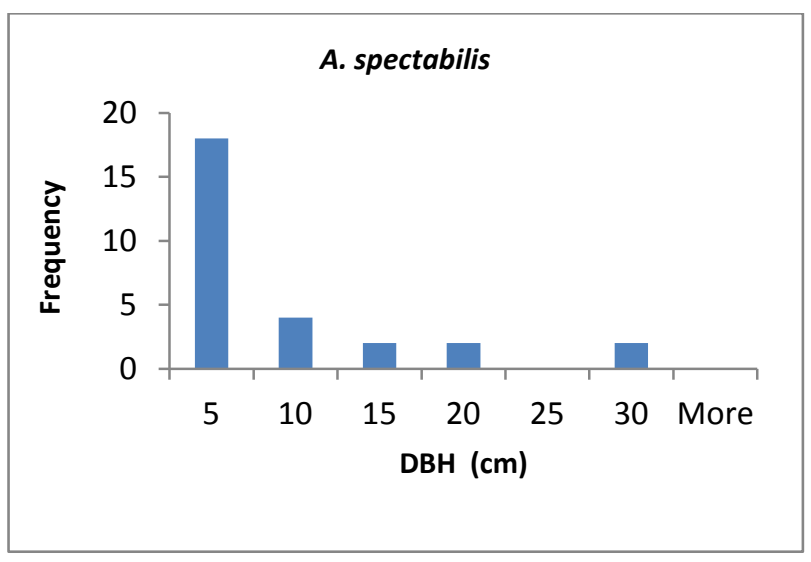

Fig. 10. DBH class distribution of Abies spectabilis, Kalchuman Tal Area of Manaslu Conservation Area, central, Nepal.

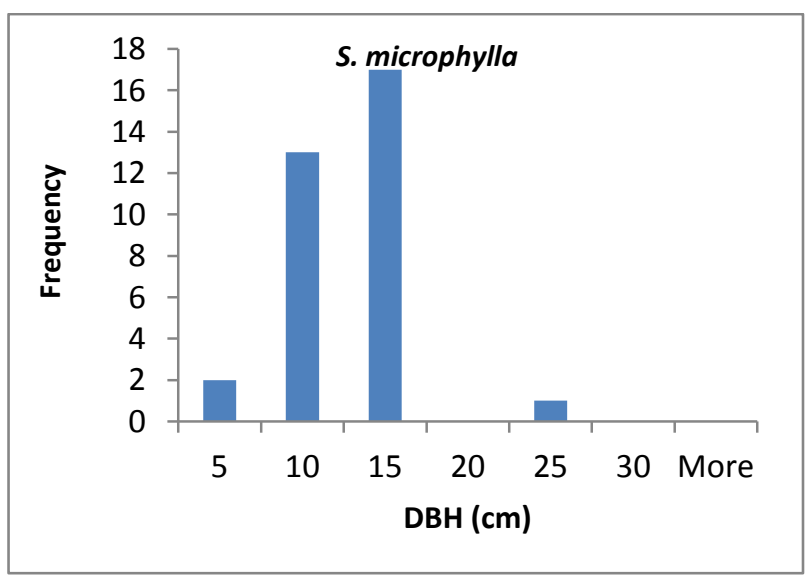

Fig. 11. DBH class distribution of Sorbus microphylla, Kalchuman Tal Area of Manaslu Conservation Area, central, Nepal.

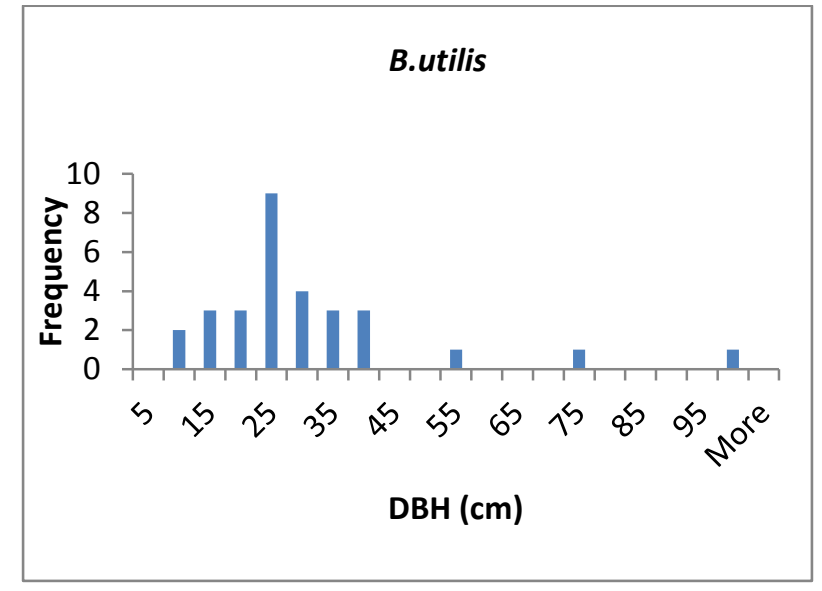

Fig. 12. DBH class distribution of Betula utilis, Kalchuman Tal Area of Manaslu Conservation Area, central, Nepal.

The diameter class showed an inverse $\mathbf{J}$ frequency distribution for Rhododendron campanulatum and Abies spectabilis which is an indication of sustainable regeneration (Fig. $9 \&$ 10). Paul (2008) reported similar findings from temperate broadleaf forest of Rhododendrons. Gaire et al. (2010) reported inverse J shaped diameter class distribution was observed for $R$. campanulatum in Langtang. Whereas, Betula utilis and Sorbus microphylla showed a bell shaped distribution which indicates lower regeneration in recent years (Fig. 11 \& 12). Shrestha et al. (2007) reported that $B$. utilis both in mixed and pure forests nearly resembled a reverse $\mathbf{J}$ shaped in the forest of trans Himalaya dry valley in Manang, Central Nepal. Gaire et al. (2015) reported a slightly inverse $\mathrm{J}$ and bell shaped DBH distribution for A. spectabilis and $B$. utilis respectively at Sagarmatha (Everest) National Park. Bhuju et al. (2010) reported a bell shaped diameter class for A. spectabilis and B. utilis at Yaren plot and Debuche plot (Everest region of Nepal) respectively while A. spectabilis and $B$. utilis showed a reverse $\mathbf{J}$ distribution in Debuche and Yaron plot respectively. Ghimire and Lekhak (2007) found an inverse $\mathrm{J}$ shaped size class distribution for $B$. utilis and A. spectabilis in the northern aspect of Manang. The diameter class distribution class of $A$. spectabilis and B. utilis is site specific. $R$. campanulatum and $S$. microphylla were also found above the treeline.

\section{CONCLUSION}

The present study shows that Rhododendron campanulatum, Betula utilis, Abies spectabilis and 
Sorbus microphylla are the treeline species in the study site. Results reveal that $R$. campanulatum was the most dominant species along the elevational gradient with highest IVI value. At $4000 \mathrm{~m}$ asl $S$. micorphylla was the codominant species. B.utilis was the codominant species from 3600 to $3900 \mathrm{~m}$ asl followed by $S$. microphylla and A. spectabilis. $R$. campanulatum and $A$. spectabilis showed a sustainable regeneration pattern. While $B$. utilis and $S$. microphylla showed poor regeneration. Lack of seedling of Betula might be due to unfavorable microhabitat (dense) which may lead to replacement by more shade tolerant $A$. spectabilis at lower elevation. At higher elevation just below the treeline dense $R$. campanulatum may be crucial factor inhibiting seedling growth. The height, diameter and density differed along the elevational gradient and showed a species specific trend. The data obtained from this study could be used as baseline reference for future studies.

\section{REFERENCES}

Arista, M. 1995. The structure and dynamics of an Abies pinasapo forest in southern Spain. Forest Ecology and Management 74:81-89.

Bai, F., Weiguo, S and Axmacer, J. C. 2001. Forest vegetation response to climate and environmental change. A case study from Chanbai Mountain, NE China. Forest Ecology and Management.262:2052-2060.

Block, J. and Treter, U. 2001. The limiting factors at the upper and lower forest limits in the mountain-woodland steppe of Northwest Mongolia Jaochim Block and Uwe Treter (In: Kaennel Dobbertin, Ed O. U Braker). Proceedings of the International Conference on Tree Rings and People, Davos, pp 22-26.

Bhuju, D. R., Carrer, M., Gaire, N. P., Soraruf, L., Riondato, R. Salerno, F., et al. 2010. Dendrochoronological study of high altitude forest at Sagarmatha National Park, Nepal. In: Contemporary research in Sagarmatha (Mt. Everest region, Nepal edited by: Jha, P.K and Khanal, I.P, Nepal Academy of Science and Technology, Laltipur, 119-130, 2010.

Camarero, J. J. and Gutiérrez, E. 2004. Pace and pattern of recent tree line dynamics: response of ecotones to climatic variability in the Spanish Pyrenees, Climatic Change 63:181200.
Grabher, G. Gottfriend, M. and Pauli, H. 1994. Climate effects on mountain plants. Nature 369:448.

Gaire, N. P., Dhakal, Y. R., Lekhak, H. C., Bhuju, D. R. and Shah, S. K. 2010. Dynamics of Abies Spectabilis (D Don.) in relation to climate change at the Tree line ecotone of Langtang National Park, Nepal Himalaya. Nepal Journal of Science and Technology 12: 220-229.

Gaire, N. P., Bhuju, D. R., Koirala, M. and Borgaonkar, H. P. 2014. Treeline dynamics with climate change at central Nepal Himalaya. Climate of the Past 10: $1277-$ 1290.

Gaire, N. P., Rana, P. Koirala, M, Bhuju, D. R. and Carrer, M. 2015. Study of treeline ecotone to assess long-term impact of environmental change in Mt. Everest Region, Nepal Himalaya. FUUAST Journal of Biology 5 (1):1-11.

Ghimire, B and Lekhak, H. D. 2007. Regeneration of Abies spectabilis (D. Don) Mirb in subalpine forest of upper Manang, NorthCentral Nepal. Local effects of global change in the Himalayas; Manang Nepal. Chapter 10 Eds. R.P. Chaudhary, T.H Aase, O. R. Vetaas, Subedi B. P. Publishers: Tribhuvan University of Bergen, Norway, pp139-149.

Ghimire, B., Mainali K. P., Lekhak, H. D., Chaudhary, R. P. and Ghimeray, A.K. 2010. Regeneration of Pinus wallichiana $\mathrm{AB}$ Jackson in a trans-Himalayan dry valley of north-central Nepal. Himalayan Journal of Sciences 6(8):19-26.

Grime, J. P. 2001. Plant strategies, vegetation process and ecosystem properties. Chichester, United Kingdom: Wiley.

IPCC. 2014. Summary for policymakers. In: Climate Change 2014: Impacts, Adaptation, and Vulnerability. Part A: Global and Sectoral Aspects. Contribution of Working Group II to the Fifth Assessment Report of the Intergovernmental Panel on Climate Change [Field, C. B., V. R. Barros, D. J. Dokken, K. J. Mach, M. D. Mastrandrea,T.E. Bilir, M. Chatterjee, K. L. Ebi, Y. O. Estrada, R. C. Genova, B. Girma, E. S. Kissel, A. N. Levy, S. MacCracken, P. R. Mastrandrea, and L. L. White (eds.). Cambridge University Press, Cambridge, United Kingdom and NewYork, NY, USA, pp. 1-32. 
Kershaw, K. A. 1973. Quatitative and Dynamics Plant Ecology. Edward Arnold Ltd (Second Edition), London .U. K.

Kullman, L. 2002. Rapid recent range-margin rise of tree and shrub species in the Swedish Scandes, Journal of Ecology 90: 68-77.

Kullman, L. 2007. Tree line population monitoring of Pinus Sylvestri in the Swedish Scandes, 1973-2005: implications for tree line theory and climate change ecology. Journal of Ecology 95:41-52.

Lingua, E., Cherubini, P., Motta, R. and Nola, P. 2008. Spatial structure along an altitudinal gradient in the Italian Central Alps suggest competition and facilitation among coniferous species 19:425-36.

Liang, E., Dawadi, B, Pederson, N. and Eckstein, D. 2014. Is the growth of birch at the upper timberline in the Himalaya limited by moisture of by temperature? Ecology 95(9)2014:2453-2465.

Liu, Q. 2004. The effects of gap size and within gap position on the survival and growth of natural regenerated Abies georgei seedlings. Acta Pytoecologica Sinica 28 (2):204-209.

NTNC. 2010. Annual Report, National Trust for Nature Conservation, Satdobato, Lalitpur, Nepal.

Paul A, 2008. Studies on the diversity and regeneration ecology of Rhododendron in Arunchal Pradesh. PhD thesis, Assam University, Silchar, India.

Payette, S., Fillion, L., Delwaide, A. and Begin, C. 1989. Reconstruction of tree-line vegetation response to long-term climate change. Nature 341:429-31.

Penuelas, J., Ogaya, R. and Boada, M. 2007. Migration, invasion and decline: changes in recruitment and forest structure in a warming linked shift of Europeon beech forest in Cataloni (NE Spain). Ecography 30:829-37.

Schickoff, U., Bobrowski, M., Bohner, J, Burzle, B., Chaudary, R.P., Gerlitz, L., et al. 2015. Do Himalayan Treelines respond to recent climate change? An evaluation of sensitive indicators. Earth System Dynamics 6: 245265.

Shrestha, A. B., Wake, C. P., Mayewski, P. A. and Dibb, J. E. 1999. Maximum temperature trend in the Himalaya and its vicinity: An analysis based on temperature records from
Nepal for period 1971-94. Journal of Climate 12: 2775-2787.

Shrestha, B. B., Ghimire, B. K., Lekhak, H. D. and Jha, P. K. 2007. Regeneration of treeline birch (Betula utilis D. Don) forest in a transHimalayan dry valley in central Nepal. Mountain Research and Development 27(3): 259-267. doi:10.1659/mrdd.0784.

Shrestha, U. B., Shrestha, S., Chaudhary, P. and Chaudhary, R. P. 2010. How Representative is the Protected Areas System of Nepal? A Gap Analysis Based on Geophysical and Biological Features. Mountain Research and Development 30:282-294.

Sujakhu, H. 2013. Forest structure and regeneration of Betula utilis D. DON in Manaslu Conservation Area, Nepal. Department of Environmental Science. Khwopa College (affiliated to Tribhuvan University).

Tesfeya, G., Teketay D., Fetene, M. and Beck, F. 2010. Enumeration of seven indigenous tree species in a dry montane forest, southern Ethopia. Flora- Morphology, Distribution, Functional Ecology of Plants 205 (2):135143.

Veblen, T. T. 1989. Nothofagus regeneration in treefall gaps in northern Pategonia. Canadian Journal of Forest Research 19:365-371.

Wangda, P. and Ohsawa, M. 2006. Structure and regeneration dynamics of dominant tree species along altitudinal gradient in a dry valley slopes of Bhutan Himalaya. Forest Ecology and Management 230:136-50.

Wang, T., Liang, Y., Ren, H., Yu, D., Ni, J. and Ma, K. 2004. Age structure of Picea schrenkiana forest along an altitudinal gradient in the central Tianshan Mountains, northwestern China. Forest Ecology and Management 196:267-74.

Wang, W., Franklin, S. B., Ren, Y. and Oullette, J. R. 2006. Growth of bamboo of Fargesia quinlingensis and regeneration of trees in a mixed hardwood-conifer forest in the Quinling Mountains, China. Forest Ecology and Management 196: 267-274.

Whittaker, R. H.1956. Vegetation of the great smoky mountains. Ecological Monographs 26:1-26.

Wardle, P. 1971. An explanation for alpine timberline, New Zealand. Journal of Botany 9:371-402. 